\section{Osteocalcin Immunohistochemical Expression During Repair of Critical- Sized Bone Defects Treated with Subcutaneous Adipose Tissue in Rat and Rabbit Animal Model}

Correspondence: Profa. Dra. Tatiana Miranda Deliberador, Rua Prof. Pedro Viriato Parigot de Souza, 5300, Campo Comprido, 81280-330 Curitiba, PR, Brasil. Tel: +55-41-3317-3403. e-mail: tdeliberador@gmail.com
Thalyta Verbicaro, Allan Fernando Giovanini, João Cesar Zielak, Flares Baratto

Filho, Melissa Rodrigues de Araujo, Tatiana Miranda Deliberador
The aim of this study was to evaluate the osteocalcin immunoexpression during the bone repair treated with subcutaneous adipose tissue in rats and rabbits. Fourteen rats and 14 rabbits were used in the study. A critical-sized calvarial defect was created in each animal. The animals were divided into 4 experimental groups: RC (rat control), $\mathrm{RbC}$ (rabbit control), RAT (rat adipose tissue), RbAT (rabbit adipose tissue). In the groups $\mathrm{RC}$ and $\mathrm{RbC}$ the defect was filled with a blood clot. In groups RAT and RbAT, the defect was filled with macerated subcutaneous adipose tissue. The euthanasia was performed at 30 days (RC and RAT) and 40 days (RbC and RbAT). Histological analysis and immunohistochemical analysis of osteocalcin protein expression were performed. Data were submitted to descriptive statistical analysis (mode). Osteocalcin immunoexpression was detected in the experimental models. Notwithstanding, RbAT showed higher positivity, especially in the adipocytes, than the group RAT group. In groups $\mathrm{RC}$ and $\mathrm{RbC}$, the surgical wound was filled by collagen fibers. In Group RAT, the defect was composed by collagen fibers and adipocytes in the reparative sites. Similarly, in RbAT, the defect also was partially filled by collagen fibers and presence of adipocytes dispersed among the fibers. Additionally, chronic inflammatory process and areas of bone matrix deposition were observed. It may be concluded that in both animal models the adipose tissue demonstrated low osteogenic capacity. However, the rabbit animal model exhibited a more evident osteocalcin immunoexpression and a greater amount of newly formed bone matrix.
Key Words: abdominal fat, subcutaneous fat, stem cells, rabbits, bone regeneration, osteocalcin.

\section{Introduction}

The bone tissue has high capacity of healing, but bone grafts have been used to aid the repair in cases of large defects. The autogenous bone is considered the gold standard for bone repair, but with the advancement of biotechnology new techniques and alternative biomaterials have been studied in order to influence the bone formation process (1).

In this way, adult stem cells derived from adipose tissue aroused interest in regenerative medicine because of their capacity of differentiating into skeletal, cartilaginous (2), endothelial (3), myogenic (4) and neural (5) tissues. Moreover, the adipose tissue may influence in bone homeostasis by producing hormones, proteins and growth factors $(6,7)$. Scherberich et al. (8) reported that the nonadipose portion of this tissue is rich in endothelial and mesenchymal progenitor cells, suggesting a source of osteogenic and vasculogenic cells. The stromal vascular fraction in adipose tissue has approximately $2 \%$ stem cells with potential to differentiate into several multicell lines that include osteoblasts, chondrocytes, adipocytes and neural cells, while the bone marrow has only $0.002 \%$ of these progenitor cells (9).

There are currently two main types of adipose tissue: brown and white (10). The white adipose tissue comprises a matrix of connective tissue, nervous tissue, cells of vascular stroma, lymph nodes, immune cells, fibroblasts and stem cells (6) and it presents two distributions in the organism: subcutaneous and visceral or abdominal adipose tissue (11).

Adipokines produced by the subcutaneous adipose tissue favor the bone metabolism because they may influence both the energetic homeostasis and immunological response. Moreover, the white adipose tissue is rich in CD34+ cells that have a potential to differentiate into osteogenic and endothelial cells when they are stimulated by chemotactic factors and cytokines, favoring neovascularization $(2,3,5,12)$. However, the subcutaneous adipose tissue used as graft has exhibited controversial results in bone 
treatment. Recent histological studies $(12,13)$ reported that macerated adipose tissue might favor bone repair when applied to craniofacial defects. On the other hand, Matsubara et al. (14) reported the use of adipose tissue graft to treat peri-implant dehiscence, indicating that the presence of adipose tissue could act as a barrier for new bone formation.

The aim of this study was to evaluate osteocalcin immunoexpression and histological features produced during repair in critical-sized bone defects treated or not with subcutaneous adipose tissue in two different animal models (rat and rabbit).

\section{Material and Methods}

The Ethics Committee of Positivo University, Curitiba, $\mathrm{PR}$, Brazil approved the research protocol (Registration number 009/2009 and 019/2009). Fourteen Wistar rats (Rattus albinus) and 14 rabbits (Oryctolargus cuniculus) were divided into the following groups: $\mathrm{RC}$ (rat control), RAT (rat adipose tissue), RbC (rabbit control) and RbAT (rabbit adipose tissue) $(n=7)$. The animals were maintained in a room with controlled temperature (approximately $22^{\circ} \mathrm{C}$ ) and maintained under a $12 \mathrm{~h}$ light/dark cycle.

\section{Surgical Procedures of Rats}

The animals were sedated by oxygen and isoflurane (Cristália, Itapira, SP, Brazil) inhalation and anesthetized with an intramuscular injection of xylazine hydrochloride $(0.52 \mathrm{mg} / \mathrm{kg})$ (Vetbrands, Paulínia, SP, Brazil) and ketamine hydrochloride (1.04 mg/kg) (Vetbrands).

After shaving and asepsis with topical 10\% polyvinylpyrrolidone iodine of the areas to be operated, the calvaria was accessed through a U-shaped incision made with a \#15 scalpel blade to obtain a total thickness flap with its base towards posterior. A critical-sized transosseous defect (CSD) with a $5 \mathrm{~mm}$ diameter was created with a 5-mm trephine bur (Neodent ${ }^{\oplus}$, Curitiba, PR, Brazil), reaching the sagittal suture. The bone block was removed with elevators to avoid a meningeal rupture. With the aid of periodontal probe (PCPUNC 15; Hu-Friedy, Chicago, IL, USA) and a \#701 carbide bur in a straight handpiece, two L-shaped marks were made at $2 \mathrm{~mm}$ anteriorly and $2 \mathrm{~mm}$ posteriorly to the surgical defect margins. The long axis of each L-shaped mark was located on a longitudinal imaginary line dividing the surgical defect in half. The marks were filled with dental amalgam (Permite; SDI, Bayswater, Vic, Australia) (Fig. 3c) and they were intended to identify the middle of the surgical defect during the laboratory processing and to locate the original bone margins for the histological analysis.

To obtain the autologous subcutaneous adipose tissue, an approximate $1 \mathrm{~cm}$ wide incision was made with a $15 \mathrm{C}$ blade on the abdominal area, parallel to the right hind of the rats. The adipose tissue of abdominal area was biopsied with scissors and tweezers. The adipose tissue collected was macerated with $15 \mathrm{C}$ scalpel blade and immediately transplanted into the artificial surgical bone defect in the RAT group, while the group $\mathrm{RC}$ received blood clot.

In both receptor and donor sites, the soft tissues were sutured with 4-0 silk thread (Ethicon; Johnson \& Johnson, São José dos Campos, SP, Brazil). At the end of the surgery, the rats received morphine sulphate $(3 \mathrm{mg} / \mathrm{kg}$; União Quimica, São Paulo, SP, Brazil) intramuscularly and the analgesia was maintained with 20 drops of paracetamol $(200 \mathrm{mg} / \mathrm{kg}$ ) diluted in $400 \mathrm{~mL}$ water, for 3 days.

\section{Surgical Procedures on Rabbits}

The rabbits received enrofloxacin $(0.1 \mathrm{~mL} / \mathrm{kg}$; Baytril; Bayer S.A., São Paulo, SP, Brazil) and midazolam (1 mg/kg; União Química) intramuscularly $1 \mathrm{~h}$ prior to the surgical procedure to promote sedation. Anesthesia was achieved with a combination of 10\% ketamine hydrochloride (35 $\mathrm{mg} / \mathrm{kg}$ i.m.; Syntec, Cotia, SP, Brazil) and 2\% xylazine hydrochloride ( $5 \mathrm{mg} / \mathrm{kg}$ i.m.; Vetbrands). An access through the marginal vein of the ear was made to maintain anesthesia during the surgery.

After shaving and asepsis with topical 10\% polyvinylpyrrolidone iodine of the areas to be operated, a V-shaped incision was made on the calvaria with a 15C scalpel blade, and a partial-thickness flap was raised towards posterior direction. Another $\mathrm{V}$-shaped incision was made on the periosteum to enable raising the periosteum towards the posterior. A 15-mm diameter critical-sized transosseous defect was created with a customized trephine bur and the bone block was removed with a Molt elevator. L-shaped marks were made in the same way as described for the rats. The methodology described by Torres et al. (15) was used to obtain the subcutaneous adipose tissue in the rabbits. The adipose tissue was macerated with $15 \mathrm{C}$ scalpel blade and immediately transplanted into the artificial surgical bone defect in the RbAT group, while in the group $\mathrm{RbC}$ the defect was filled with blood clot.

In the donor site, first intention closure of the incision was achieved. In the receptor site, suture was performed in two phases: the periosteum was sutured with absorbable thread (Medcryl 4-0, MedEvolution, Tamil Nadu, India) and the dermis and epidermis with 4-0 silk thread (Ethicon, Johnson \&t Johnson). The animals received daily intramuscular injections of enrofloxacin $(5 \mathrm{~mL} / \mathrm{kg}$ body weight) for 5 days. To control the pain, a morphine injection ( $3 \mathrm{mg} / \mathrm{kg}$ i.m.) was administered at the end of the surgery and $4 \mathrm{~h}$ after the first application. Analgesia was maintained with paracetamol $(200 \mathrm{mg} / \mathrm{kg})$ diluted in water, every $8 \mathrm{~h}$ for 5 days. 
The euthanasia of animals in groups RC and RAT occurred 30 postoperatively using gas chamber, while in groups $\mathrm{RbC}$ and $\mathrm{RbAT}$ the euthanasia occurred 40 postoperatively with an endovenous administration of $10 \mathrm{~mL} / \mathrm{kg}$ of 2.5\% sodium thiopental (Cristália). In each animal, the calvaria was removed in block and the surgical fragments obtained were fixed in 10\% formalin. For the histological analysis, $3 \mu \mathrm{m}$ serial slices were obtained and stained with hematoxylin and eosin (HE).

For the immunohistochemical anti-peroxidase analysis, osteocalcin antibody $(200 \mu \mathrm{g} / \mathrm{ml}$; Santa Cruz Biotechnology Inc., Santa Cruz, CA, USA) was employed using a standard streptavidin-biotin immunoperoxidase method. The material was embedded in paraffin and $3-\mu \mathrm{m}-$ thick histological slices were obtained, deparaffinized and hydrated. A 10-min bath in 10\% ammonium hydroxide and $95 \%$ ethanol was carried out to remove the formalin pigments, followed by running and distilled water washing. To achieve the antigen recovery from the tissue, the slices were incubated with $1 \%$ pepsin solution, $\mathrm{pH}=1.8$, at $37{ }^{\circ} \mathrm{C}$ for $60 \mathrm{~min}$. The specimens were then subjected to washing and blockage with $3 \%$ hydrogen peroxide $\left(6 \% \mathrm{H}_{2} \mathrm{O}_{2}\right.$ solution in distilled water at 1:1 ratio), and the solution was removed by washing in running water, followed by two changes of distilled water.

In order to not alter significantly the $\mathrm{pH}$, the cuts underwent a fast incubation in PBS buffer solution (BSA; Biotest S/A, São Paulo, SP, Brazil) at a $0.2 \mathrm{M}$ concentration and $\mathrm{pH}$ 7.4. The slides were incubated with the primary antibody (polyclonal osteocalcin) for $18 \mathrm{~h}$ (overnight) at 4 ${ }^{\circ} \mathrm{C}$, in a moist chamber at a $1: 100$ dilution in PBS solution added with $1 \%$ bovine albumin containing $0.1 \%$ sodium azide. The same cuts were used as negative control instead of incubating the primary antibody. The LSAB kit (DAKO number $K 0,690$ ) was used during the incubation of the secondary and complex tertiary antibodies (streptavidin biotin peroxidase), according to the manufacturer's instructions.

To reveal the reaction, the specimens were incubated in $300 \mathrm{mg}$ of diaminobenzidine as chromogen (3,3-diaminobenzidina; Sigma Chemical CO., St. Louis, $\mathrm{MO}$, USA) in $100 \mathrm{~mL}$ PBS buffer solution, $\mathrm{pH} 7.4$, previously filtered and activated by induction of $600 \mu \mathrm{L}$ of $6 \% \mathrm{H}_{2} \mathrm{O}_{2}$ at room temperature, for $3 \mathrm{~min}$ in a dark chamber. The slides were counter-stained with Harris hematoxylin for 3 min followed by washing. The slides underwent dehydration by ascending ethanol series, followed by clearing in xylene and mounted on Permount ${ }^{\oplus}$ (Fischer Scientific, Fair Lawn, NJ, USA) for analysis in light microscopy.

The images for each field were obtained in light microscope at $400 \times$ magnification. The images were captured with a camera system (SDC-310 Samsung, South
Korea) associated to light microscope (021/3; Quimis, Diadema, SP, Brazil). In all histological specimens, manual counting of the positive expression for osteocalcin protein was carried out twice by a single examiner. In order to obtain and evaluate the histological and immunostaining data, a semi-quantitative score was established by the following criteria: "-" from lack of staining up to $1 \%$ immunopositivity; "+" from 1 to $25 \%$; "++" from 25 to $50 \%$; "+++" from 50 to 75\%, and "++++" for more than 75\%. This semi-quantitative immunohistochemical analysis was performed because the osteocalcin proteins were expressed both in the cells and extracellular matrix.

\section{Results}

\section{Qualitative Histological Analysis}

In groups $\mathrm{RC}$ and $\mathrm{RbC}$, the surgical wound was completely composed by collagen fibers parallel to the defect. Neither osteoblast proliferation nor acute or chronic inflammatory process was observed (Fig. 1).

The group RAT exhibited complete filling of the surgical wound by collagen fibers and adipocytes dispersed in the collagen tissue. Among the adipocytes, the beginning of the osteoid matrix deposition was seen, but a larger new bone formation occurred on the artificial defect margins (Fig. 2).

The surgical defect of group RbAT was partially filled by bundles of dense collagen fibers with adipocytes dispersed among the fibers. There was new bone formation among the adipocytes and the endosteum exhibited active conjunctive tissue. On the surface of the defect, far from the original margin, a chronic inflammatory process could be seen surrounding the adipose tissue. However, there was evidence of new bone formation on the area closer to the original bone (Figure 3).

\section{Qualitative Immunohistochemical Analysis}

In groups $\mathrm{RC}$ and $\mathrm{RbC}$, the surgical area was composed by collagen fibers. The fibers exhibited brownish color indicating that there was expression of osteocalcin (Fig. 4).

The groups RAT and RbAT showed images with positive immunoexpression, but in some areas there was a higher expression of the protein. Positive areas were seen among the adipocytes. The bone tissue of the defect margins was also positive for osteocalcin, suggesting active bone matrix production. Notwithstanding, RbAT exhibited a higher osteocalcin immunoexpression among the adipocytes than that of RAT (Fig. 5).

\section{Quantitative Histological Analysis}

The results of the quantitative histological analysis and the quantitative immunohistochemical analysis of osteocalcin expressionare presented in Tables 1 and 2, respectively. 

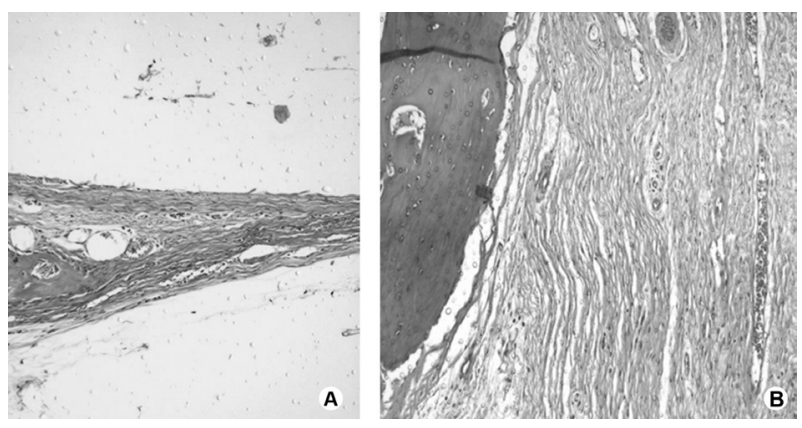

Figure 1. A: RC 30 days postoperatively. Bone defect completely filled by collagen fibers (HE 100x magnification). B: $\mathrm{RbC} 40$ days postoperatively: surgical defect filled by collagen fibers dispersed parallel to the defect. Blood vessels can be observed (HE 100x magnification).
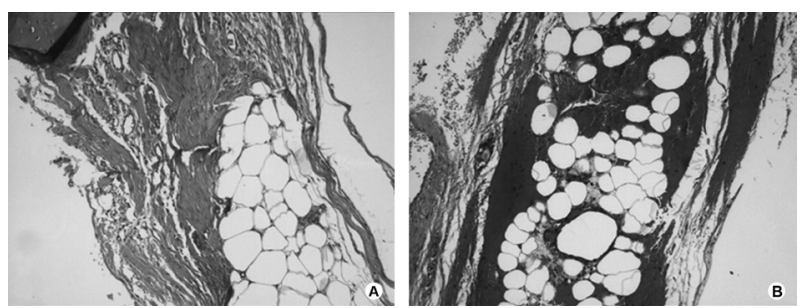

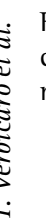

Figure 2. A,B: RAT 30 days postoperatively. Surgical wound filled by collagen fibers and remaining adipocytes. The beginning of osteoid matrix formation is observed (HE 100x magnification).
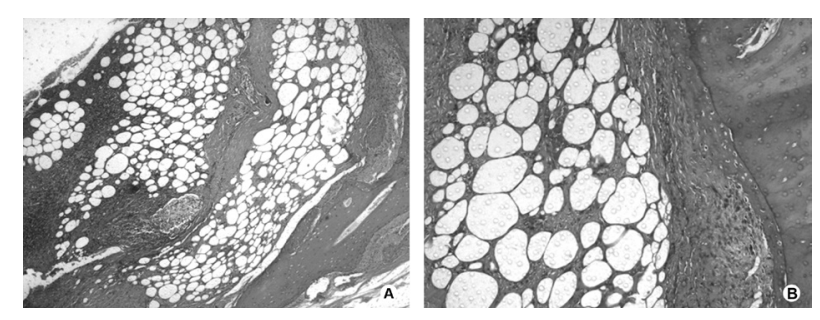

Figure 3. A,B: RbAT 40 days postoperatively. Surgical wound partially filled by collagen fibers and remaining adipocytes. A chronic inflammatory process and active endosteum is observed (HE 100× magnification).

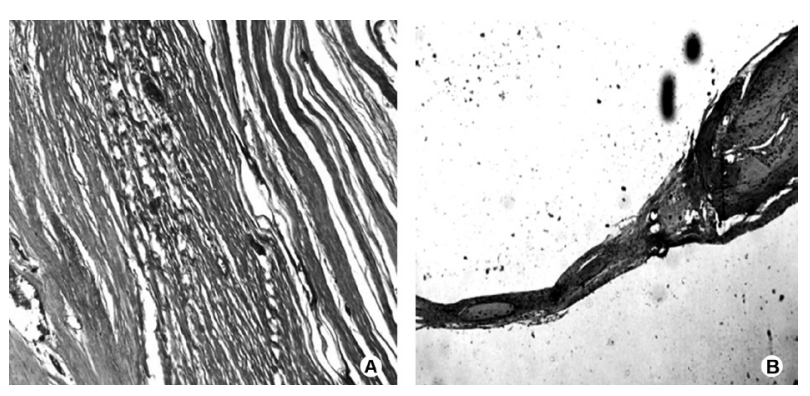

Figure 4. Immunostaining of osteocalcin among groups. A: positive immunostaining for group $\mathrm{RbC}$ at 40 days postoperatively (osteocalcin 100x magnification). B: positive immunostaining for group RC at 30 days postoperatively (osteocalcin $40 \times$ magnification).

\section{Discussion}

The adipose tissue has gained interest in regenerative therapeutics because it influences the bone homeostasis by the production of hormones, cytokines, growth factors and other peptides $(6,7)$. Adipose tissue grafting has been used in facial aesthetic procedures and reconstruction of healing tissue (16). Moreover, this tissue can be an alternative for liver transplant and treatment of urinary tract diseases (17).

In Dentistry, the adipose tissue grafting techniques have been used to close oral-sinus communication (18) and root recovering because these techniques are easy to be performed and have promising results, providing a considerable amount of keratinized tissue when under in the coverage of maxillary molar roots (19). Additionally, the buccal fat pad has been employed successfully to treat Class II furcation defects as a barrier for guided tissue regeneration (20).

The macerated adipose tissue grafting has been histologically studied to treat cranial bone defects with promising results because the maceration separates the CD34+ cells from adipose tissue matrix, facilitating the transdifferentiation when in contact with the bone.

Table 1. Score (mode) of the amount of bone matrix, fibrous tissue, adipose tissue and inflammatory process within the surgical defect for groups RC, RbC, RAT, RbAT

\begin{tabular}{lcccc}
\hline & $\mathrm{RC}$ & $\mathrm{RbC}$ & $\mathrm{RAT}$ & $\mathrm{RbAT}$ \\
\hline Bone matrix & - & - & + & ++ \\
Fibrous tissue & ++++ & ++++ & ++ & ++ \\
Adipose tissue & - & - & +++ & +++ \\
Inflammatory process & - & - & + & ++ \\
\hline
\end{tabular}

Table 2. Score (mode) of osteocalcin immunoexpression for bone matrix in groups $\mathrm{RC}, \mathrm{RbC}, \mathrm{RT}, \mathrm{RbAT}$

\begin{tabular}{ccccc}
\hline & $\mathrm{RC}$ & $\mathrm{RbC}$ & $\mathrm{RAT}$ & $\mathrm{RbAT}$ \\
\hline Osteocalcin & - & - & + & ++ \\
\hline
\end{tabular}
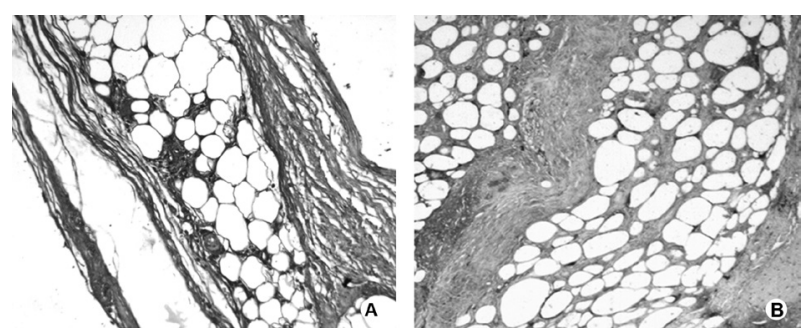

Figure 5. Immunostaining of osteocalcin among groups. A: positive immunostaining for RAT group at 30 days postoperatively (osteocalcin $100 \times$ magnification). B: Positive immunostaining for RbAT group at 40 days postoperatively (osteocalcin 100x magnification). 
Additionally, grafting without laboratory processing decreases the cost and time of the treatment $(2,12,13)$.

In the present study was evaluated the immunohistochemical expression of osteocalcin during bone repair in critical-sized defects treated with subcutaneous adipose tissue graft both in rats and rabbits. This procedure was used in order to verify if there would be difference in bone repair between the animal models. This hypothesis seems to be plausible because histological studies using subcutaneous adipose tissue applied in the bone tissue treatment in rats and rabbits showed controversial results. Oliveira et al. (13) demonstrated that the grafting favored bone repair, while Gorny-Junior et al. (21) concluded that grafting prevented repair.

Group RbAT results were more promising than those of Group RAT, which could be explained by the donor region of the adipose tissue in each type of animal. In rabbit model, the tissue was collected at the dorsum area, while in rat model it was collected from the abdominal area containing a great amount of visceral adipose tissue that might be collected together with the abdominal adipose tissue.

Barrera et al. (2012) reported that the visceral adipose tissue within epididymis increases the energetic effectiveness of the tissue but it does not interfere in glucose consumption. On the other hand, the study of Tran and Kahn (5) demonstrated that the subcutaneous adipose tissue improves the glucose homeostasis and increases energy consumption, benefiting the tissue metabolism. Those authors suggested that the subcutaneous adipose tissue metabolism is more accelerated than the visceral tissue. Similar results could be observed in this study, as the group RAT exhibited an active endosteum and a larger new bone formation than the group $\mathrm{RC}$, suggesting that the subcutaneous adipose tissue leads to a faster bone repair.

Moreover, the subcutaneous adipose tissue is rich in CD34+ cells. This glycoprotein accounts for the cellular adhesion and it has been applied in the treatment of severe ischemia and to form vascular anastomosis because it has potential for differencing into endothelial cells $(5,8,23)$. This adipose tissue has the capacity to induce neoangiogenesis, favoring tissue repair, and this fact might have occurred in the group RbAT. Based on the forementioned information, the use of subcutaneous adipose tissue may be justified.

The rabbit has a faster metabolism than other animals. It is considered mistakenly as a fragile animal when actually its accelerated metabolism enables that both tissue repair and pathological conditions occur rapidly. The rabbit has resistance as high as the pig and thus can be used in research studies (24). Based on these facts and according to the obtained results, it may be suggested that the tissue repair in the RbAT group was faster because of the rabbit's faster metabolism.
In the present study, two experimental time periods were studied: 30 postoperative days for rats and 40 postoperative days for rabbits aiming to observe the maturation of bone repair by the immunoexpression of osteocalcin. Considering that the rabbit has a faster metabolism, its postoperative period was 10 days longer, which could have favored the better outcomes with this animal.

Osteocalcin immunostaining occurred in both animal models. This protein is commonly produced by mature osteoblasts and is deposited onto the extracellular matrix indicating bone repair (25). Notwithstanding, group RbAT exhibited a marked immunoexpression within the adipocytes and new bone formation in the defect area closer to the original bone than those of group RAT. Conversely, in groups $\mathrm{RC}$ and $\mathrm{RbC}$, defect healing was achieved by collagen fibers without osteoblast proliferation, showing that the transosseous defect did not favor bone repair.

Using histological analysis, Gorny Junior et al. (21) evaluated the bone repair of transosseous defect in rat calvaria after autogenous bone graft combined with subcutaneous adipose tissue gathered from the abdomen. The authors observed presence of heterotopic bone formation and necrotic areas composed by microcystic and liquefactive degeneration on $15^{\text {th }}$ day post surgery. In the present study, on the contrary, necrotic areas were not observed.

Using macerated subcutaneous adipose tissue for the treatment of rabbit calvaria, Oliveira et al. (13) demonstrated intensive bone formation in the adipose tissue. The authors concluded that the adipose tissue might be considered a good grafting biomaterial for bone repair. Corroborating with the results of Oliveira et al. (13), a similar conclusion may be drawn from the present study in rabbit models, as RbAT exhibited important formation of osteoid matrix among the adipocytes and intense mature new bone formation on the border of the original defect.

In contrast to the present results, Matsubara et al. (14) demonstrated that non-processed adipose tissue is not an adequate substitute for autogenous bone in the treatment in dehiscent bone defects surrounding implants. This important difference among the results occurred possibly because those authors did not macerate the tissue. The maceration releases water, dissolves the contact surface of the cell and favors the transdifferentiation.

Further studies with longer experimental periods are necessary to assess the use of subcutaneous adipose tissue because at 30 and 40 postoperative days it was still observed a great amount of remaining adipose tissue and collagen fibers. Thus, it may be stated that the adipose tissue showed slow resorption and transdifferentiation in both animal models. Moreover, the adipose tissue graft can be considered as a space maintaining material with low 
osteogenic capacity because it did not favor bone repair in the postoperative periods established in this study.

In conclusion, there was osteocalcin immunoexpression in both animal models. Notwithstanding, in rabbits the immunoexpression was more evident, with greater amount of newly formed matrix among the adipocytes. Thus, it is suggested that the rabbit should be the animal of choice to the study on subcutaneous adipose tissue grafting because of its easy collection and faster metabolism.

\section{Resumo}

Este estudo avaliou a imunoexpressão da osteocalcina no reparo ósseo de defeitos críticos tratados com tecido adiposo subcutâneo em rato e coelho. Foram utilizados 14 ratos e 14 coelhos. Um defeito crítico foi realizado na calvária de cada animal. Os animais foram divididos em 4 grupos experimentais: CR (controle rato), CC (controle coelho), TAR (tecido adiposo do rato), TAC (tecido adiposo do coelho). Nos grupos CR e CC, o defeito foi preenchido com coágulo. Nos grupos TAR e TAC, o defeito foi preenchido com tecido adiposo subcutâneo macerado. A eutanásia dos grupos CR e TAR ocorreu com 30 dias e dos grupos CC e TAC com 40 dias. Foram realizadas análise histológica e imunoistoquimica com a proteína osteocalcina. Os dados foram submetidos à análise estatistica descritiva (moda). Nos modelos experimentais foi observada a imunoexpressão de osteocalcina. Contudo, o TAC apresentou maior imunoexpressão entre os adipócitos quando comparado ao TAR. Nos grupos CR e CC a ferida cirúrgica foi preenchida por fibras colágenas. No grupo TAR foi observado o preenchimento por fibras colágenas e presença de adipócitos no interior $\dot{\Xi}$ deste tecido. No grupo TAC o defeito foi preenchido parcialmente por fibras colágenas, com presença de adipócitos dispersos entre as fibras. Além disso, foi observado processo inflamatório crônico e sinais de neoformação óssea. Conclui-se que em ambos os modelos animais o enxerto de tecido adiposo apresentou baixa capacidade osteogênica. Contudo, o modelo animal coelho apresentou uma imunoexpressão da osteocalcina mais evidente e maior quantidade de matriz óssea neoformada.

\section{References}

1. Butler $D L$, Goldstein SA, Guilak F. Functional tissue engineering: the role of biomechanics. J Biomech Eng 2000;122:570-575.

2. Zou J, Wang G, Geng D, Zhu X, Gan M, Yang H. A novel cell-based therapy in segmental bone defect: using adipose derived stromal cells. J Surg Res 2011;168:76-81.

3. Cao Y, Sun Z, Liao L, Meng Y, Han Q, Zhao RC. Human adipose tissuederived stem cells differentiate into endothelial cells in vitro and improve postnatal neovascularization in vivo. Biochem Biophys Res Commun 2005;332:370-379.

4. Lee JH, Kemp DM. Human adipose-derived stem cells display myogenic potential and perturbed function in hypoxic conditions. Biochem Biophys Res Commun 2006;341:882-888.

5. Tran $\Pi$, Kahn CR. Transplantation of adipose tissue and stem cells: role in metabolism and disease. Nat Rev Endocrinol 2010;6:195-213.

6. Fruhbeck G, Gomez-Ambrosi J, Muruzabal FJ, Burrell MA. The adipocyte: a model for integration of endocrine and metabolic signaling in energy metabolism regulation. Am J Physiol Endocrinol Metab 2001;280:E827-847.

7. Bucky LP, Percec I. The science of autologous fat grafting: views on current and future approaches to neoadipogenesis. Aesthet Surg J 2008;28:313-321;22-24.
8. Scherberich A, Muller AM, Schafer DJ, Banfi A, Martin I. Adipose tissuederived progenitors for engineering osteogenic and vasculogenic grafts. J Cell Physiol 2010;225:348-353.

9. Strem $B M$, Hedrick MH. The growing importance of fat in regenerative medicine. Trends Biotechnol 2005;23:64-66.

10. Bauer-Kreisel P, Goepferich A, Blunk T. Cell-delivery therapeutics for adipose tissue regeneration. Adv Drug Deliv Rev 2010;62:798-813.

11. Pischon T, Boeing H, Hoffmann K, Bergmann M, Schulze MB, Overvad $\mathrm{K}$, et al.. General and abdominal adiposity and risk of death in Europe. N Engl J Med 2008;359:2105-2120.

12. Gomes SP, Deliberador TM, Gonzaga CC, Klug LG, da Costa Oliveira $L$, de Andrade Urban C, et al.. Immediate transplant of fragmented autogenous white adipose tissue: A histomorphometric and immunohistochemical study. J Craniofac Surg 2012;23:1-6.

13. Oliveira LD, Giovanini AF, Abuabara A, Klug LG, Gonzaga CC, Zielak JC, et al.. Fragmented adipose tissue graft for bone healing: histological and histometric study in rabbits' calvaria. Med Oral Patol Oral Cir Bucal 2013;18:e510-e515.

14. Matsubara FB, Zanicotti DG, Zielak JC, Giovanini AF, Gonzaga CC, de Andrade Urban $C$, et al.. Nonprocessed adipose tissue graft in the treatment of dehiscence bone defects in rabbit tibiae: a pilot study. Implant Dent 2012;21:236-241.

15. Torres FC, Rodrigues CJ, Stocchero IN, Ferreira MC. Stem cells from the fat tissue of rabbits: An easy-to-find experimental source. Aesth Plast Surg 2007;31:574-578.

16. Karagianni M, Kraneburg U, Klüter H, Machens HG, Bieback K, Schantz JT, et al.. Autologous fat grafts and supportive enrichment with adipose tissue stromal cells. Handchir Mikrochir Plast Chir 2013;45:93-98.

17. Zimmerman $\mathrm{HA}$, Olson $\mathrm{KC}$, Chen $\mathrm{G}$, Lynch CJ. Adipose transplant for inborn errors of branched chain amino acid metabolism in mice. Mol Genet Metab. 2013;109:345-353.

18. Allais M, Maurette PE, Cortez ALV, Laureano Filho JR, Mazzonetto R. The buccal fat pad graft in the closure of oroantral communications. Rev Bras Otorrinolaringol 2008;74:799-809.

19. El Haddad SA, Abd El Razzak MY, El Shall M. Use of pedicled buccal fat pad in root coverage of severe gingival recession defect. J Periodontol 2008;79:1271-1279.

20. Deliberador TM, Mendes RT, Storrer CLM, Giovanini AF, Zielak JC, Lopes TR. Autogenous bone graft combined with buccal fat pad as barrier in treatment of Class II furcation defect: A case report. Bull Tokyo Dent Coll 2012;53:127-132.

21. Gorny Jr CL, Giovanini, AF, Vieira, JS, Zielak, JC, Santos FR, Storrer CLM, Deliberador TM. Immunoexpression of bmp-2 protein on bone repair critical size defects treated with autogenous macerated adipose tissue. RSBO, 2014 (In Press).

22. Barrera C, Gatica A, Morgan C. Obese visceral adipose tissue grafted in lean mice can alter glucose homeostasis and energy efficiency. J Biol Regul Homeost Agents 2012;26:411-417.

23. Guo $S$, Cheng $Y, M a Y$, Yang $X$. Endothelial progenitor cells derived from CD34+ cells form cooperative vascular networks. Cell Physiol Biochem 2010;26:679-688.

24. Lebas F. Available at: http://www.cuniculture.info/Docs/Biologie/ Biologie-50.htm

25. Chenu C, Colucci $S$, Grano M, Zigrino P, Barattolo R, Zambonin G, et al.. Osteocalcin induces chemotaxis, secretion of matrix proteins and calcium-mediated intracellular signaling in human osteoclast-like cells. J Cel Biol 1994;127:1149-1158. 